\title{
"The peculiarities of establishing the charter air transportation: European experience in Ukraine"
}

\begin{tabular}{|c|c|}
\hline \multirow{9}{*}{ AUTHORS } & Tetyana Prymak (D https://orcid.org/0000-0003-0682-8717 \\
\hline & $\mathbb{R}$ https://publons.com/researcher/1777127/tetyana-prymak/ \\
\hline & Liubov Ivchenko (D https://orcid.org/0000-0003-4937-1112 \\
\hline & R https://publons.com/researcher/1775240/liubov-ivchenko/ \\
\hline & Nataliia Pohuda (D https://orcid.org/0000-0002-8926-9350 \\
\hline & $\mathbb{R}$ https://publons.com/researcher/2122871/nataliia-viktorivna-pohuda/ \\
\hline & Valentyna Levchenko (D https://orcid.org/0000-0001-8444-5960 \\
\hline & Viktor Trynchuk (D https://orcid.org/0000-0001-7435-0159 \\
\hline & R https://publons.com/researcher/1367594/viktor-trynchuk/ \\
\hline ARTICLE INFO & $\begin{array}{l}\text { Tetyana Prymak, Liubov Ivchenko, Nataliia Pohuda, Valentyna Levchenko and } \\
\text { Viktor Trynchuk (2020). The peculiarities of establishing the charter air } \\
\text { transportation: European experience in Ukraine. Innovative Marketing , 16(1), 43- } \\
\text { 56. doi:10.21511/im.16(1).2020.05 }\end{array}$ \\
\hline DOI & http://dx.doi.org/10.21511/im.16(1).2020.05 \\
\hline RELEASED ON & Thursday, 20 February 2020 \\
\hline RECEIVED ON & Sunday, 29 December 2019 \\
\hline \multirow[t]{2}{*}{ ACCEPTED ON } & Friday, 31 January 2020 \\
\hline & $((c))$ EY \\
\hline LICENSE & $\begin{array}{l}\text { This work is licensed under a Creative Commons Attribution } 4.0 \text { International } \\
\text { License }\end{array}$ \\
\hline JOURNAL & "Innovative Marketing " \\
\hline ISSN PRINT & $1814-2427$ \\
\hline ISSN ONLINE & $1816-6326$ \\
\hline PUBLISHER & LLC "Consulting Publishing Company "Business Perspectives" \\
\hline FOUNDER & LLC "Consulting Publishing Company "Business Perspectives" \\
\hline
\end{tabular}

NUMBER OF REFERENCES

42

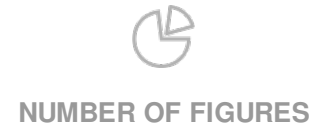

6

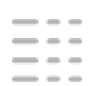

NUMBER OF TABLES

3

(C) The author(s) 2022. This publication is an open access article. 


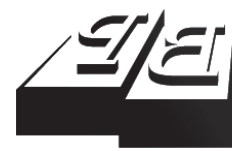

\section{BUSINESS PERSPECTIVES}

LLC "CPC "Business Perspectives" Hryhorii Skovoroda lane, 10, Sumy, 40022, Ukraine www.businessperspectives.org

Received on: $29^{\text {th }}$ of December, 2019 Accepted on: $31^{\text {st }}$ of January, 2020 Published on: $20^{\text {th }}$ of February, 2020

(C) Tetyana Prymak, Liubov Ivchenko, Nataliia Pohuda, Valentyna Levchenko, Viktor Trynchuk, 2020

Tetyana Prymak, Ph.D. (Physics and Mathematics), Associate Professor, National University of Food Technologies, Ukraine.

Liubov Ivchenko, Ph.D. (Physics and Mathematics), Associate Professor, National University of Food Technologies, Ukraine.

Nataliia Pohuda, Ph.D. (Economics), Associate Professor, Simon Kuznets Kharkiv National University of Economics, Ukraine.

Valentyna Levchenko, Doctor of Economics, Associate Professor, Kyiv National University of Technologies and Design, Ukraine.

Viktor Trynchuk, Ph.D. (Economics), Associate Professor, National University of Food Technologies, Ukraine.
Tetyana Prymak (Ukraine), Liubov Ivchenko (Ukraine), Nataliia Pohuda (Ukraine), Valentyna Levchenko (Ukraine), Viktor Trynchuk (Ukraine)

\section{THE PECULIARITIES \\ OF ESTABLISHING THE CHARTER AIR TRANSPORTATION: EUROPEAN EXPERIENCE IN UKRAINE}

\begin{abstract}
This paper highlights the problems associated with the poor quality of services and the lack of effective marketing interaction between all the participants of the charter air transportation in the tourist summer season of 2018 in Ukraine. The paper aims to develop an algorithm for the actions of all participants of tourist services market in order to establish effective marketing interaction based on the analysis of the reasons influencing the destabilization of the tourist services market in the field of charter air transportation. Flight delay statistics were selected for June-July 2018 due to the fact that it was during this period that the problem manifested itself especially sharply. So, not time-series data, but cross-sectional data were selected for the analysis of the problem cause. At the same time, for confident conclusions about the increase in passenger traffic, 5-year periods were chosen, namely, the period 2014-2018 was compared with the period 2009-2013. During the research, statistical methods of one-factor linear correlation-regression analysis were used, as well as a comparative analysis of the in dicators of the charter air transportation participants' performance in Ukraine. The analysis of charter air transportation market showed that increasing the age of the aircraft in a year leads to a decrease in the proportion of timely flights by $2.5 \%$. The marketing analysis proves that the rapid increase in the number of passengers was caused by the explosive increase in irregular flights. The results of the study also indicate that the well-organized interaction between the tour operator and the airlines significantly affects the timeliness of the flights. Based on defined problems of the charter air transportation market, a set of recommendations has been proposed for improving the marketing interaction of all market participants: tourists, tour operators, airlines and government agencies.
\end{abstract}

\section{Keywords \\ marketing, marketing interaction, tourism, charter air transportation, flight delay, quality of services, Ukrainian airlines}

JEL Classification M31, L93, L83

\section{INTRODUCTION}

Air transportation in the world and in Ukraine in particular has shown a steady growth trend over recent years. Further maintaining this trend is expected for a number of reasons, the main of which are lowering the cost of tariffs, which makes air transportation more affordable, developing the famous ones and opening new tourist destinations, respectively. The popularity of this type of transport is explained by the increase in the number of tourist destinations and the possibility of quick access to them since each year airlines try to reduce the time spent in the air. Along with this, the number of short-stay tours over long distances increases, so the determining factor is speed. The increase in the number of passengers will be mainly due to emerging markets. In this sense, Ukraine is one of the most promising countries in Europe. Charter flights, along with regular flights and low-cost airlines, occupy their niche in the air transportation market. 
Ukraine, which in recent years has also experienced a boom in irregular flights, which in 2017 increased by $48 \%$ compared to 2016 , was not an exception. This is explained primarily by the fact that the tourist services market in Ukraine is one of the most dynamic in recent years, where the number of people wishing to rest is increasing each year, but the unevenness in demand and supply leads to an imbalance in the tourist services market. An indication of this was the situation in the summer of 2018, when airlines and tour operators failed to fulfill their obligations to tourists.

The situation with the legal regulation of charter flights and the provision of appropriate services to passengers when tourists are blocked at airports without normal conditions of stay has exacerbated the key issues in the work of both tour operators and airlines. As quality of tourist services are the result of the interaction of many partners it is necessary to identify the causes of the situation and to suggest ways of fruitful marketing interaction of the tourist services market participants.

\section{LITERATURE REVIEW}

The quality of tourist services depends significantly on the quality of each of the components of the tourism product, as well as on the level of marketing interaction (Boiko, Bosovska, Vedmid, Melnychenko, \& Okhrimenko, 2017, p. 134; Mazaraki, Boiko, Okhrimenko, Melnychenko, \& Zubko, 2019, p. 94; Okhrimenko, Boiko, Bosovska, Melnychenko, \& Poltavska, 2019, p. 170) of the tourist services market. Especially critical from this point of view is that aviation is seen as the first, initial stage, which can become a significant barrier to receiving the tourist services, and eventually will even spoil the impression of the rest of the services. Therefore, the issue of marketing interaction between airlines and tour operators is very relevant.

Several scientific papers are devoted to studying the peculiarities of airlines' operations, their legal regulation, and of charter flights (Nesimko, 2015, pp. 181-183; Popov, 2016, pp. 151-152; Oleshko, Heyets, \& Pavlyuk, 2017; Oleshko \& Heiets, 2018, p. 1), whose research is aimed at not only defining the legislative framework for the functioning of the aviation industry but also analyzing the main problems and ways to overcome them. Significant attention is paid to the operator of Ukrainian airlines and the work of airports in Ukraine.

As it was already noted, there is an inextricable relationship between the development of air transportation market and tourism, which is reflected in the works of Balabanov and Tkachuk (2010), Birzhakov (2003), Doktorov and Myshkyna (2016), Smirnov (2009). Significantly contributed to the study of this problem Buck and Lei (2004, pp. 7274), Dobruszkes, Koo, and Lim (2017), Doganis (2001), Graham (2006, pp. 14-17), Forsyth (2006, p. 5), Lintz, Muller, and Schmude (2007, pp. 513515), Papatheodorou (2006), Zhang and Findlay (2014, pp. 42-44), etc.

Charter flights are a kind of air transportation that allows minimizing the expenses of tour operators for transportation of passengers by means of contractual relationship between tour operator and airlines.

Based on the analysis of scientific works and definite approaches, charter flights can be defined as irregular flights, which airlines make on request, in the vast majority of tour operators, according to predefined directions and frequencies.

Consequently, charter air transportation covers both representatives of the air and tourism business; therefore, it is important to have effective legal regulation of their activities, to determine the peculiarities of each of them and to establish liability to each participant.

The specifics of the tourism business lies in combining the various types of service - transport, food, accommodation, consular services, etc., which are regulated by the state authorities. Each of these bodies affects the individual segments of the tourism industry through a large number of regulatory acts, which are often incoherent and contradictory.

The main body regulating tourism in Ukraine is the Department of Tourism and Resorts of the Ministry for Development of Economy, Trade and 
Agriculture of Ukraine. The general principles of the implementation of state policy in tourism activities are defined by the Law of Ukraine "On Tourism" (Legislation of Ukraine, 1995). State regulation of activity in the field of aviation and use of airspace of Ukraine is carried out by the State Aviation Administration of Ukraine of the Ministry of Infrastructure of Ukraine (SAAU, 2018). The main regulatory act regulating the general principles of airlines' activity is the Air Code of Ukraine (Legislation of Ukraine, 2011). The legal basis for the joint operation of the airlines and tour operator is the standard bilateral agreement developed by the International Air Transport Association IATA (IATA, 2004), which contains the basic principles of commercial cooperation. The basis for such agreements is the Convention on the Unification of Certain Rules for International Air Transportftion (Legislation of Ukraine, 1998), which defines the responsibilities of the airlines to the passenger for any flights, including the irregular ones.

In organizing charter flights, the tour operator, together with the airlines, determines the route, stipulates the obligations of the parties, checks the conformity of the lease agreement with international rules, calculates the cost of the flight. Furthermore, there comes a special charter agreement, according to which the airlines almost always put the tour operator in tough conditions. The cost of charter air transportation (Duncan, 2005; Sarsfield, 2018) is determined by many factors under this agreement between the airlines and the tour operator who is the consumer of air transportation services, the so-called consolidator of charter air transportation, which, in turn, can resell seats on the flight to other tour operators. This tariff is significantly lower than regular service tariffs; however, this value is guaranteed to the airlines by the consolidator who should fill the flight on its own.

\section{RESEARCH PURPOSE}

The article aims to develop an algorithm for the actions of all participants of air transportation market in order to establish effective marketing interaction based on the analysis of the reasons influencing the destabilization of the tourist services market in the field of charter air transportation.

\section{RESEARCH METHOD}

The study used statistical methods of one-way linear correlation and regression analysis, as well as a comparative analysis of the performance indicators of air transportation market participants in Ukraine.

The simplest version of the linear model, which is often used in the analysis of the time series, can be represented as follows:

$$
y_{i}=a_{0}+a_{1} x_{i}+\varepsilon_{i},
$$

where $a_{0}$ is a mathematical expectation of a dependent variable $y_{i}$ when the variable $x_{i}=0, a_{1}$ is an angular coefficient, the value of which shows the average change in the dependent variable $y_{i}$ when the variable $x_{i}$ changes by one, $\varepsilon_{i}$ is a random error.

In the process of construction of linear regression models, they were not supposed to be used for forecasting; therefore, the adequacy of the models was assessed by the coefficient of determination without statistical criteria, for example, the Fisher criterion. The admissibility of an unambiguous interpretation of the obtained results, depending on the degree of correlation, is discussed during the presentation of the main results of the work.

The methods of comparison and analysis are based on statistical information of the aviation market in the world and Ukraine. They serve as the basis for the extension of this approach to the activities of a particular air carrier. In this article, the authors have collected secondary data (statistical and analytical reports) from many different sources, such as the Ministry of Infrastructure of Ukraine, the State Aviation Administration of Ukraine, and EUROCONTROL. The methods of scientific abstraction and synthesis of scientific ideas are used in this work as well.

\section{RESULTS}

The charter flight is a lot different from the regular flight (see Table 1), in particular, the lack of direct relationship between the airlines and the passenger until the registration in the airport since 
all the connections the tourist has with the tour operator. Therefore, in cases of delayed flights or their transfer, the tourist uses an agent who sold the service.

Table 1. The main differences between charter flights and regular flights

Source: Authors' compilation.

\begin{tabular}{|c|c|c|}
\hline \multirow{2}{*}{ Characteristics } & \multicolumn{2}{|c|}{ Type of flight } \\
\hline & Charter & Regular \\
\hline Time of departure & $\begin{array}{l}\text { Based on the } \\
\text { previous agreement } \\
\text { with the tour } \\
\text { company }\end{array}$ & On schedule \\
\hline Time spent in the air & $2-4$ hrs & $1 \mathrm{hr}$ and more \\
\hline Connections & Not available & $\begin{array}{l}\text { Available, depends } \\
\text { on the destination }\end{array}$ \\
\hline Booking the ticket & Not available & Available \\
\hline Buying the ticket & As a part of a tour & $\begin{array}{l}\text { Self-bought from } \\
\text { the tour operator or } \\
\text { from an agent }\end{array}$ \\
\hline Refunding the ticket & Not available & $\begin{array}{l}\text { As discussed in the } \\
\text { rate rules }\end{array}$ \\
\hline Ticket price & $\begin{array}{l}\text { Lower than usual, } \\
\text { the same for all } \\
\text { passengers }\end{array}$ & $\begin{array}{l}\text { Higher, depends on } \\
\text { the service quality }\end{array}$ \\
\hline Place on the plane & $\begin{array}{l}\text { Similar for all } \\
\text { passengers }\end{array}$ & $\begin{array}{l}\text { Depends on the } \\
\text { class of service }\end{array}$ \\
\hline Bonus miles & Are not accrued & Are accrued \\
\hline Complaints & $\begin{array}{l}\text { To the airlines or } \\
\text { the agent who sold } \\
\text { the service }\end{array}$ & $\begin{array}{l}\text { Immediately to the } \\
\text { airlines }\end{array}$ \\
\hline
\end{tabular}

Consequently, the choice of a charter flight has its advantages for a tourist, in particular: tickets for this flight are much cheaper, compared with regular; lack of transfers, since the specifics of this type of transportation is direct communication; mobility of access to the necessary destination because for mass tourism only charter flights can get tourists to the destination quickly (on an hourly basis) and without connections.

At the same time, while certain qualities only seem like advantages at first glance, there may also be disadvantages under certain conditions: since the main criterion is the cheapness of the flight, the tourist chooses unreliable airlines, resulting in a delayed flight, its changes, or in general, refusal to perform the flight; inability to refund tickets; permanent delays, due to the priority of regular aircraft service in the airports.

Comparing regular charter flights, it can be noted that the passenger of this type of transportation is limited both in the choice of airlines and in the unsecured financial guarantee plan. Besides, delays in sending a "package tour" cause a chain of delays in the future use of such a services tour operator's, in particular, which is much more expensive (often) than possible compensation for flight delays.

The dynamics of the development of the charter air transportation market in Europe shows a decline in the charter flights share over the last decade from $6 \%$ to $3 \%$, with waves of drops that repeat the main political and economic problems - the global economic crisis of 2008, the Arab Spring of 2010, military actions in Ukraine since 2014 and terrorist attacks in many countries and political conflicts between governments (for example, between Russia and Turkey), which had a significant impact on the development of tourism and, of course, strongly affected the charter air transportation.

2017 has shown a weak (3\%, against a fall of $15 \%$ in 2016) restoration of the market, primarily due to the renewal of charter flights from Russia to Turkey, but the general trend is evident - just as the proportion of individual tours is increasing compared to bundled offers, the low-cost segment is growing, compared to charter flights, especially in developed countries.

At the same time, in 2017, the flow of transported passengers in Poland (almost 40 million) exceeded the population of the country itself. Polish overseas tourist flow mainly is served by charter flights. The number of main registered airlines with which Polish tour operators co-operate is 126. Among Polish airlines, only LOT Polish Airlines organizes charter flights. In this case, about $97 \%$ of the charter air transportation market belongs to 25 airlines (Taylor, 2016, pp. 15-23). Interestingly, the largest airlines, a private Polish company, Enter Air, with 12 planes in its arsenal, provides more than $30 \%$ of flights and cooperates with 16 tour operators. The fleet of other, quite viable companies, which are not part of the major tour operators, is limited to 5 planes.

Foreign companies make up a large share of international charter flights in Poland, the largest of which are Czech Travel Service (18.3\%), Lithuanian Small Planet Airlines (7.5\%). There are 


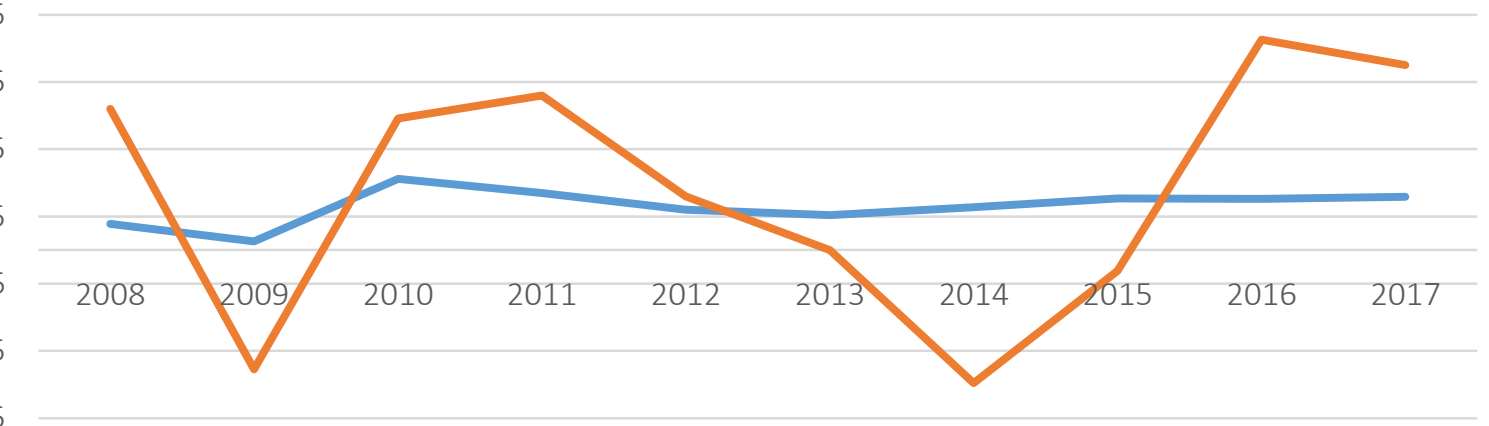

Annual growth/decrease in air transportation in the world, \%

-Annual growth/decrease in air transportation in Ukraine, \%

Figure 1. Analysis of the dynamics of air transportation in Ukraine and in the world, \%

also smaller airlines mainly from receiving countries: Egypt, Turkey, Greece, Bulgaria, Israel, and the United Arab Emirates. The co-existence of various airlines in the market is ensured by the established partnership with various tour operators.

Ukraine is not among the five leaders in terms of charter flights arrivals/departures per day (Turkey 119, Spain - 102, Germany - 101, Greece - 95, Great Britain - 86); however, it ranks second in Europe by the share of charter flights among all flights (12\%), second only to Bulgaria (20\%). On average, over the past ten years, the growth in the number of passengers in the world was $6.5 \%$, and in Ukraine, it was $9.0 \%$, but in the world, this growth was significantly more stable, gradual, less dependent on negative economic and political factors (see Figure 1).

Regular international flights from/to Ukraine in 2017 were carried out by 10 domestic airlines to 43 countries and 29 foreign airlines to 27 countries of the world. Ukrainian airlines transported 5837,5 thousand passengers on international regular flights, 4975,8 thousand passengers were served by foreign airlines (an increase of $18.1 \%$ and $29.3 \%$, respectively).

Consequently, in recent years, there has been an increase in the volume of air transportation, where in the segment of regular flights, European countries occupy the leading places, while in Ukraine, there is an increase in flights in the charter air transportation segment. In contrast to the European trend of decrease in the share of the charter air transportation, Ukraine witnessed growth in the charter flights and regular flights. In particular, according to the State Aviation Administration of Ukraine (SAAU, 2018), in recent years, there has been a rapid increase in the share of irregular flights (see Figure 2).

Source: Built based on SAAU (2018).

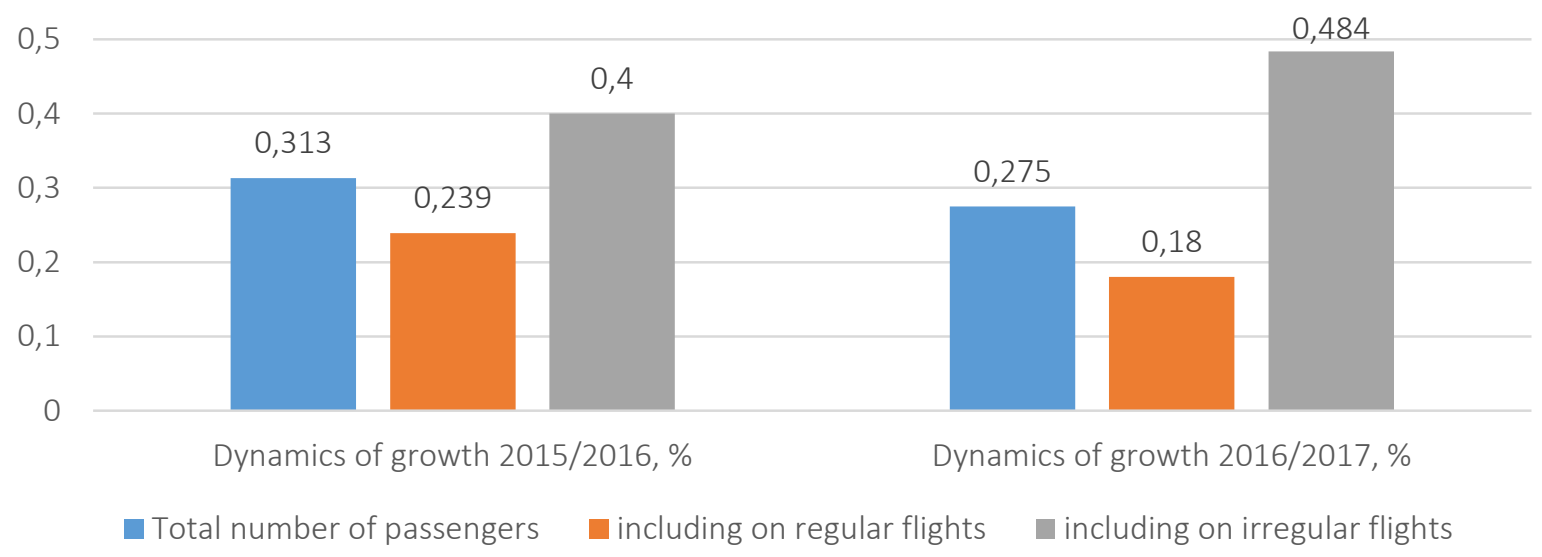

Figure 2. The dynamics of the growth of the number of transported passengers 


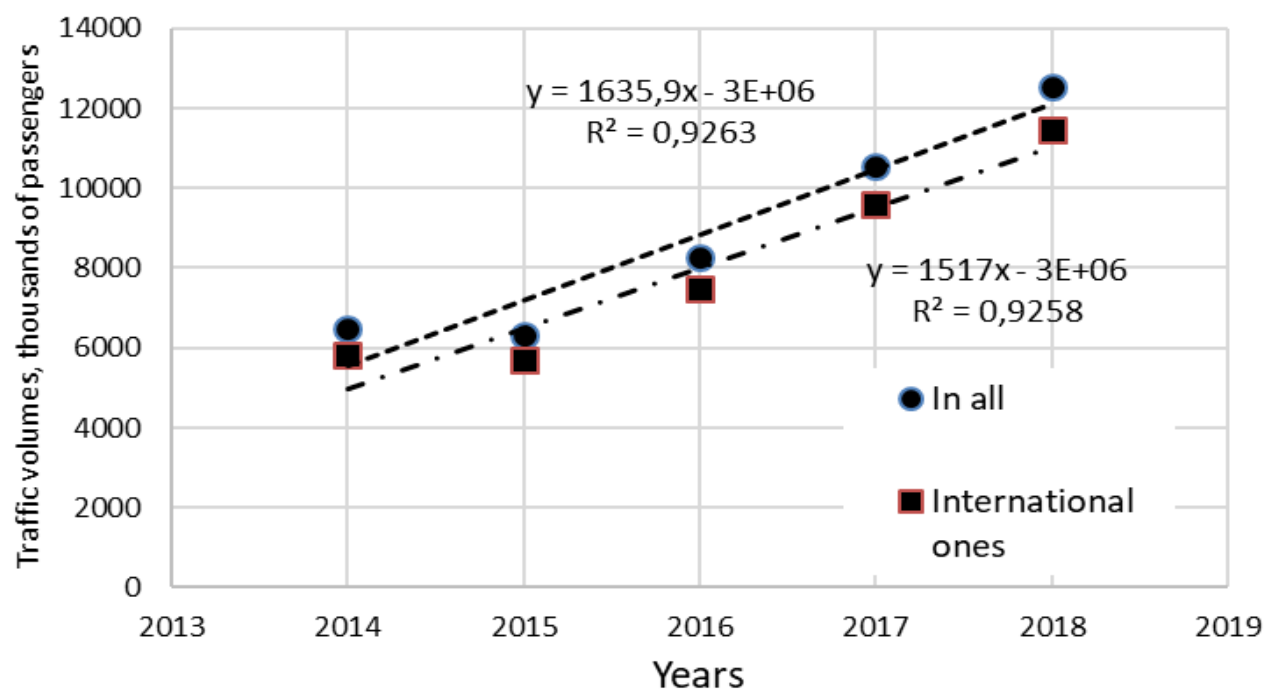

Figure 3. Estimation of growth rates of air transportation in Ukraine, 2014-2018

A simple regression analysis of flights in Ukraine allows us to quantify the average growth rate of the indicator over the last five years (2014-2018) and compare it with the average growth rate for the previous period of 2009-2013. (see Figure 3).

According to estimates of linear regression analysis during 2014-2018, the average increase in the total number of passengers was about 1636 thousand passengers, and the corresponding data for international air transportation - this is an increase of more than 1517 thousand passengers every year. Comparison with similar estimates for the period of 2009-2013 (average increase in the total number of passengers - 796 thousand passengers, and for international flights - 720 thousand passengers) showed a significant (more than twice) increase in the growth rates of flights in Ukraine.

It is obvious that the rapid increase in the number of passengers during the last three years was ensured, first of all, by an explosive, more than $40 \%$ per year, increase in irregular flights, and in general during 2015-2017, the number of passengers of irregular flights has more than doubled, rising from 1672,9 thousand to 3788,1 thousand.

This dynamic is maintained in 2018 , as statistics for this period show. In total, during this period, the growth was 18.7\% (from 10556,3 to 12529,0 thousand passengers), while the growth of regular flights was $16.2 \%$, and irregular flights continued to grow at a faster pace from 3788,1 to 4661,4 , or $23.1 \%$.

During 2018, the activation of regular flights within the borders of Ukraine continued. Regular domestic flights between 9 Ukrainian cities was performed by five domestic airlines: 1082,9 thousand passengers were transported, which is $15.1 \%$ more than in 2017.

Thus, in spite of the difficult economic and political situation in Ukraine, the growth of both flights and the number of airlines operating in tourism continues.

Ukraine has seen a marked increase in charter flights when tour operators form and operate their charter flights mainly to provide theirs services to their tourists. The destinations of charter flights correspond to the most popular tourist destinations (Turkey, Egypt, Bulgaria, Spain, Tunisia, Croatia, Cyprus, Greece); however, the dates and timetables are not clearly established, but are determined by the demand for package tours.

It should be noted that Ukrainian tour operators use the services of domestic airlines, which allows significantly reducing the costs and attracting more tourists. Therefore, it is worth analyzing the activity of Ukraine's top 5 charter airlines to determine what caused the catastrophic charter flights delays in the summer of 2018. 
The largest increase in the number of passengers transported by domestic airlines was observed in this segment of the air transportation market, as international irregular flights (49.2\%): for the reporting year, Ukrainian airlines transported 3777 thousand passengers. At the same time, six airlines carried out 95\% such flights (see Table 2).

Table 2. Growth of passenger flow of top 5 charter airlines of Ukraine during 2016-2017

\begin{tabular}{|c|c|c|c|}
\hline $\begin{array}{l}\text { Top airlines } \\
\text { in } 2016\end{array}$ & $\begin{array}{c}\text { Passenger } \\
\text { flow growth } \\
2016 / 2015, \%\end{array}$ & $\begin{array}{l}\text { Top airlines } \\
\text { in } 2017\end{array}$ & $\begin{array}{c}\text { Passenger } \\
\text { flow growth } \\
2017 / 2016, \%\end{array}$ \\
\hline $\begin{array}{l}\text { Ukraine } \\
\text { International } \\
\text { Airlines }\end{array}$ & 25 & $\begin{array}{c}\text { Ukraine } \\
\text { International } \\
\text { Airlines }\end{array}$ & 16.5 \\
\hline Windrose & 76 & Windrose & 150 \\
\hline $\begin{array}{l}\text { Azur Air } \\
\text { Ukraine }\end{array}$ & 17 & $\begin{array}{l}\text { Azur Air } \\
\text { Ukraine }\end{array}$ & 17 \\
\hline $\begin{array}{l}\text { Atlas Jet } \\
\text { Ukraine }\end{array}$ & 950 & $\begin{array}{l}\text { Atlas Jet } \\
\text { Ukraine }\end{array}$ & 74 \\
\hline YanAIR & 580 & Bravo & 50 \\
\hline
\end{tabular}

According to statistics, in 2016, the International Ukraine Airlines increased the passenger flow, compared with the previous year, by $24.9 \%$, Azure Air Ukraine - by $17 \%$, Windrose - by $75.8 \%$, YanAIR - by $6.8 \%$ times, and Atlas Jet Ukraine by $10.5 \%$ times.

As can be seen in 2017, the growth continued, albeit not at such explosive pace, except for the Windrose, which demonstrated a 2.5 times increase. The positive trend that has emerged in the last two years is primarily due to the successful development of the international air transportation market.

According to expert estimates (YouControl, 2017), only three airlines from this ranking, namely UIA, Windsrose, and Azur Air Ukraine, can be considered as stable, while the other three - Atlas Jet Ukraine, YanAIR, and Bravo are in zone of bankruptcy risk since they have a fairly low level of financial stability.

Another phenomenon in the summer of 2018 is an unlucky entry of Sky Up into the market, affiliated with the tour operator Join Up. The attempt to re-create the business model that Anex Tour Ukraine operates, together with the affiliated airlines Azur Air, has become almost fatal to the powerful tour operator Join Up, seriously undermining its market position.

The particular complexity of the problems of the charter air transportation market in Ukraine is reflected by an indicator of delays in charter flights. Starting from June 2018, the Ukrainian Ministry of Infrastructure began to monitor the punctuality ratkings, but steady statistics on the causes of delays so far, unfortunately, does not exist. In particular, according to the Ministry of Infrastructure of Ukraine (MIU, 2018), the ranking of airlines punctuality was formed (see Table $3)$.

Table 3. Indicators of the punctuality of flights by Ukrainian airlines in June-July 2018

\begin{tabular}{|c|c|c|c|c|}
\hline \multirow{2}{*}{ Airlines name } & \multicolumn{2}{|c|}{ Number of flights } & \multicolumn{2}{|c|}{$\begin{array}{c}\text { Share of timely } \\
\text { flights, \% }\end{array}$} \\
\hline & $\begin{array}{l}\text { June } \\
2018 \\
\end{array}$ & $\begin{array}{l}\text { July } \\
2018\end{array}$ & $\begin{array}{l}\text { June } \\
2018 \\
\end{array}$ & $\begin{array}{c}\text { July } \\
2018\end{array}$ \\
\hline Motor-Sich & 256 & 270 & 100 & 86.7 \\
\hline $\begin{array}{l}\text { Ukraine } \\
\text { International } \\
\text { Airlines }\end{array}$ & 3,130 & 3,448 & 98 & 73.8 \\
\hline Windrose & 531 & 620 & 98 & 90.8 \\
\hline Sky Up & 202 & 188 & 87 & 38.8 \\
\hline YanAIR & 267 & 177 & 84 & 39.0 \\
\hline Azur Air Ukraine & 262 & 268 & 82 & 67.5 \\
\hline Air-Allana & 5 & 5 & 80 & 40.0 \\
\hline FUNAir & 46 & 40 & 70 & 47.5 \\
\hline Bravo & 363 & 274 & 68 & 38.7 \\
\hline ANDA AIR & 55 & 151 & 67 & 40.4 \\
\hline Atlas Jet Ukraine & 14 & 18 & 64 & 27.8 \\
\hline
\end{tabular}

In general, the situation with the punctuality of Ukrainian airlines in June 2018 was not bad, since the average level of timely flights was $93 \%$, while in July, there was a significant deterioration in this indicator with an average of $70 \%$. It should be noted that July was characterized by a peak of a crisis situation with a delay of flights and the smallest percentage of timely charter flights being. Analysis of flights by some companies showed a very low level (28-38\%), with most of the delays was typical for charter air transportation.

At the same time, EUROCONTROL (2018) calculates the flights delay indicator, which is calculated in minutes of delay for one flight, and shows that for most popular and those that greatly contribute to the average delay time, there are two reasons 


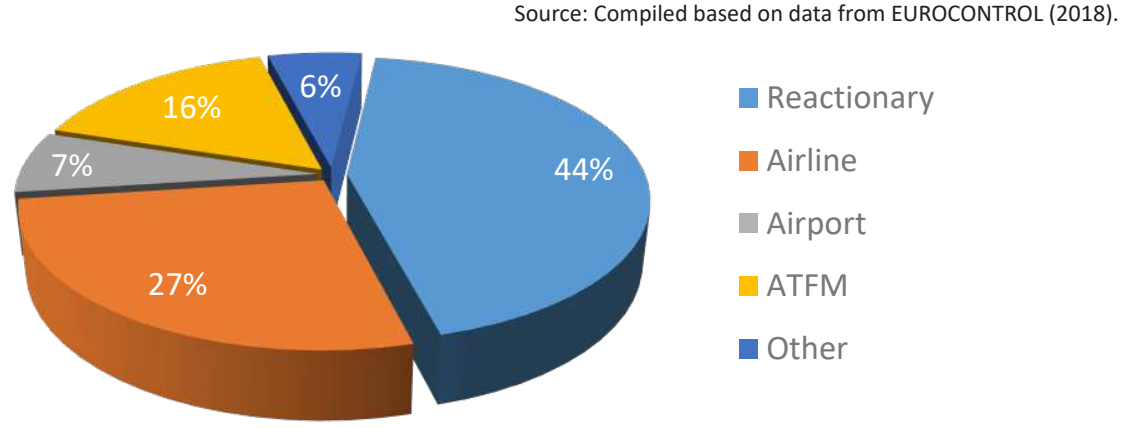

Figure 4. The main reasons for flights delays

- reactionary, connected with preliminary delays and non-arrival of the plane from previous flights on time, and delayed by the fault of the airline (see Figure 4).

The reaction to delay, although constituting $44 \%$ of all delays in Europe, is secondary as it occurs as a chain reaction to the initial delay of the flight due to other reasons earlier in time, so the focus should be on the problems of airlines delinquency since they account for $27 \%$ of all the reasons for the delay and are predominant for the initial delays.

ATFM (Air Traffic Flow Management) - flights delays that may occur on the initiative of the air traffic control service. There are many reasons for this kind of delays: weather conditions, airport capacity limitations during peak hours or days, technical problems, strikes, major sport or cultural events, etc.

Delays in the "Airport" category may be related to the readiness of the airport, the lack of timely maintenance of aviation equipment, unfavorable weather conditions at the airport, emergency situations. Delays in the category "Other" may be caused by security service, customs, or passport control.

The reasons for delays caused by the airlines, as the most significant ones, will be considered in more detail since the elimination of those significantly reduces both primary and secondary delays in servicing the passengers. The components of delays caused by the fault of the airlines may be one of the following particular factors or their combination: delay in landing; handling of baggage (including unloading of baggage of passengers who are late at the gate); cleaning, gasoline refueling, delivery of the food to the board; technical defects; problems with documents; later boarding of the crew or lack of or sickness of the crew. It is clear that besides static parameters of work, such as the technical parameters of the plane, most of these reasons can be attributed to the problems of organizing the work of the carriers themselves, which are subject to managerial control and can be significantly reduced.

It is suggested to analyze the technical condition of planes through a fleet of charter airlines (see Table 4).

Table 4. Technical characteristics of the fleet of top 5 charter airlines

Source: Compiled based on SAAU (2018).

\begin{tabular}{|c|c|c|c|c|}
\hline \multirow[b]{2}{*}{ Airlines name } & \multicolumn{3}{|c|}{ Number of planes } & \multirow{2}{*}{$\begin{array}{c}\text { Average age } \\
\text { of planes } \\
\text { in years }\end{array}$} \\
\hline & 2016 & 2017 & $\begin{array}{c}\text { Relative } \\
\text { deviation, \% }\end{array}$ & \\
\hline $\begin{array}{l}\text { Ukraine } \\
\text { International } \\
\text { Airlines }\end{array}$ & 41 & 45 & 9.8 & 12.4 \\
\hline Windrose & 11 & 11 & 0 & 15.7 \\
\hline Azur Air & 2 & 3 & 50 & 16.5 \\
\hline Atlas Jet Ukraine & 2 & 2 & 0 & 16.5 \\
\hline YanAIR & 7 & 7 & 0 & 25.4 \\
\hline Bravo & 5 & 5 & 0 & 27.0 \\
\hline
\end{tabular}

In addition to the dynamics of the increase in the number of planes, great attention should be paid to their age, as the increase in the age of planes significantly increases both the time and complexity of its maintenance, as well as the probability of malfunctions and failure in the peak moments of the tourist season.

According to the data in the table, most airlines have an insignificant, rather small, fleet of planes, 
and with a long service life. Ukraine International Airlines not only owns a large number of planes but also increased their number by three units.

Several Ukrainian airlines operating on the most popular destinations such as Dniproavia, UM Air, Anda Air have only 3 planes. Moreover, their age exceeds 17, 27 and 28 years, respectively. It is clear that with such a fleet of planes, any malfunction, delay, difficult weather conditions lead to significant consequences in the form of delays, and even the cancellation of flights. Thus, the State Aviation Service threatened to cancel the Anda Air license, when one of its planes produced in 1987 was out of order, causing a tourist collapse for the clients of the tour operator Join Up, which did not have time to put into operation the charter flights of its affiliated airlines Sky Up.

What factors affect the timeliness of flights by Ukrainian companies? According to Table 3, in July 2018, it was characterized as a boom of delays in charter flights, where the percentage of timely flights crossed a record line in the history of Ukrainian air transportation and reached its minimum (28\%). A simple regression analysis (see Figure 5), despite the rather low correlation $\left(R^{2}=0.37\right)$ between the indicator of timely flights and the average age of planes, enabled to draw interesting conclusions.

First, as expected, an increase in the age of the planes leads to a decrease in the proportion of timely flights. According to the regression analysis, an increase in the age of the planes per year reduc- es this figure by an average of $2.5 \%$.

Secondly, as can be seen from the figure, a significant decrease in the level of correlation between indicators caused a point $(16.5 ; 27.8)$, marked in Figure 6. According to the data of Table 3, Azur Air Ukraine and Atlas Jet Ukraine show significant differences in the rate of timely flights $(67.5 \%$ and $27.8 \%$ ), with planes of the same age (16.5 years). An adequate explanation for the reasons for such differences seems to be that Azur Air Ukraine is the only company owned by tour operator ANEX Tour. The result shows that the well-organized interaction between the tour operator and the airlines significantly affects the timeliness of the flights.

As one can see, in recent years, the increase in fleet has occurred only in two airlines, which, in fact, show the slightest delay and problems for tourists. The same companies, which made a significant increase in the number of passengers, showed, at the same time, the zero dynamics of the fleet, which, moreover, is old enough. The number of planes, of course, also affects the percentage of delayed flights. According to estimates of the correlation analysis for Ukrainian companies, an increase in the fleet of the company on one plane causes an increase in the share of timely flights by an average of $0.7 \%$. But because of the heterogeneity of statistical information, these estimates cannot be considered quite reliable.

The existence of contradictions in the laws and regulations issued by various ministries and departments involved in the formation of a tourist

Source: Calculated by the authors based on Tables 3 and 4 .

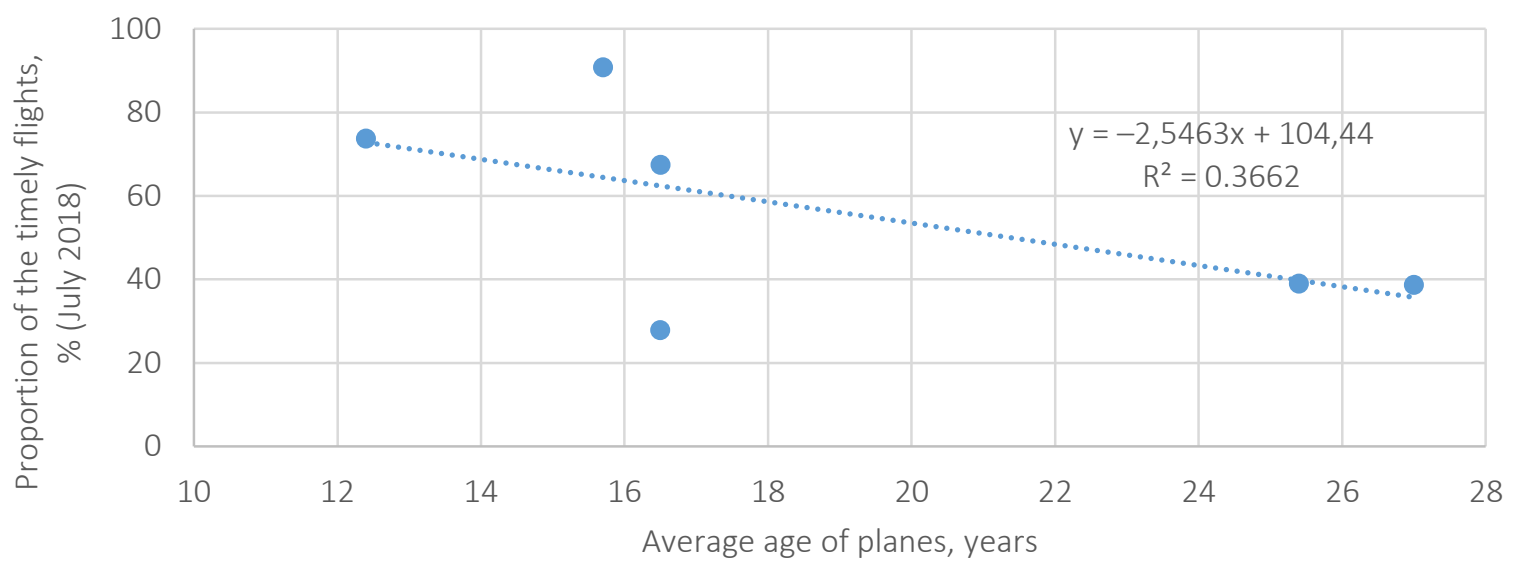

Figure 5. Linear trend for the proportion of timely flights by Ukrainian airlines depending on the average age of the planes 
product was already discussed earlier. The most influential part in providing the air transportation services to tourists is the contradictions contained in the orders of the Ministry of Infrastructure of Ukraine "On Approval of Rules for the Performance of Charter Flights" (Legislation of Ukraine, 2001) and "On Approval of Air Transport Rules for Passengers and Baggage" (Legislation of Ukraine, 2012). Under to the 2001 order, the airlines are obliged to "ensure the transportation of passengers in the opposite direction within the time limits specified in passenger tickets." At the same time, under 2012 order, the following wording is found: "Tickets for charter flights are not valid until the time when the cost of performing the charter flight is paid to airlines." Thus, the air carrier, under 2001 order, is obliged to perform a charter flight in all circumstances, and, on the other hand, has the right to refuse to perform it the absence of payment.

Problems in the relationship are added by the regulations adopted by various government organizations, which regulate only part of the activities of the companies that are subordinated to them. This, in turn, leads to inconsistencies in the interests of the market participants, and, accordingly, creation of gaps in legislative regulation (for example, as in summer of 2018 , on the liability of the parties to tourists).

It is also clear that one of the reasons for significant delays in charter flights in the summer of 2018 is a small and obsolete fleet of some Ukrainian charter airlines, which, in addition, significantly increases the volume of charter air transportation services, but does not make a corresponding increase in the technical base. Of course, the reason is, first of all, the lack of access to cheap financing for Ukrainian airlines. One of the main constraints is the fact that Ukrainian airlines do not receive long-term loans at low rates, such as in Europe. Besides, the cost-effective operation of such obsolete plane, which is already too actively used, actually almost always being in the air, requires more costs than for new plane. But the fleet renewal requires large amounts of money, and access to low-cost lending is almost impossible for Ukrainian airlines in the current economic climate.

Air business is a risky (Pyrkova, Kaigorodova, Mustafina, \& Alyakina, 2018, p. 126) and unprofit- able business that requires large amounts of money, and the lack of a sustainable investment mechanism hinders the development of airlines (Merlo, Dankiewicz, \& Ostrowska-Dankiewicz, 2013; Boiko, Bosovska, Vedmid, Bovsh, \& Okhrimenko, 2018, p. 207). Therefore, to prevent such situations, it is necessary to develop on a legislative level the mechanism of the relationship between the tour operator and the airlines, which would provide the mandatory guarantee of financial security of flights, high requirements to the material and technical base of the fleet, the number of planes, which should be owned by the airlines, clear requirements for the work of tour operators, the responsibility of each party for the provision of services.

\section{DISCUSSION}

The main conclusions and recommendations that follow from the study are based on Figure 6, where all the air transportation market participants maintain the tourist flows are presented. Consequently, all participants interact closely and depend on each other, with the key person of this process is a tourist. But quite often the mechanism of feedback of the tourists with the airlines does not work (sign "?" in the scheme) because when buying a package tour, the consumer often does not pay attention to the choice of airlines. In this regard, the end user of a tourist product - a tourist - may remain without adequate protection in case of violation of his rights as a consumer of charter air transportation services.

The close interconnection requires the formulation of recommendations for each of the air transportation market participants in the process of maintaining the tourist flows.

For tourists:

1. At the stage of choosing a travel agency and a tour operator, it is advisable to check the quality of their services through websites with reviews of tour operators (for example, www.otpusk.com, www.turpravda.ua, http:// www.turpoisk.com.ua), where there are real reviews about the work of the tour operators. It is important to pay attention to their 


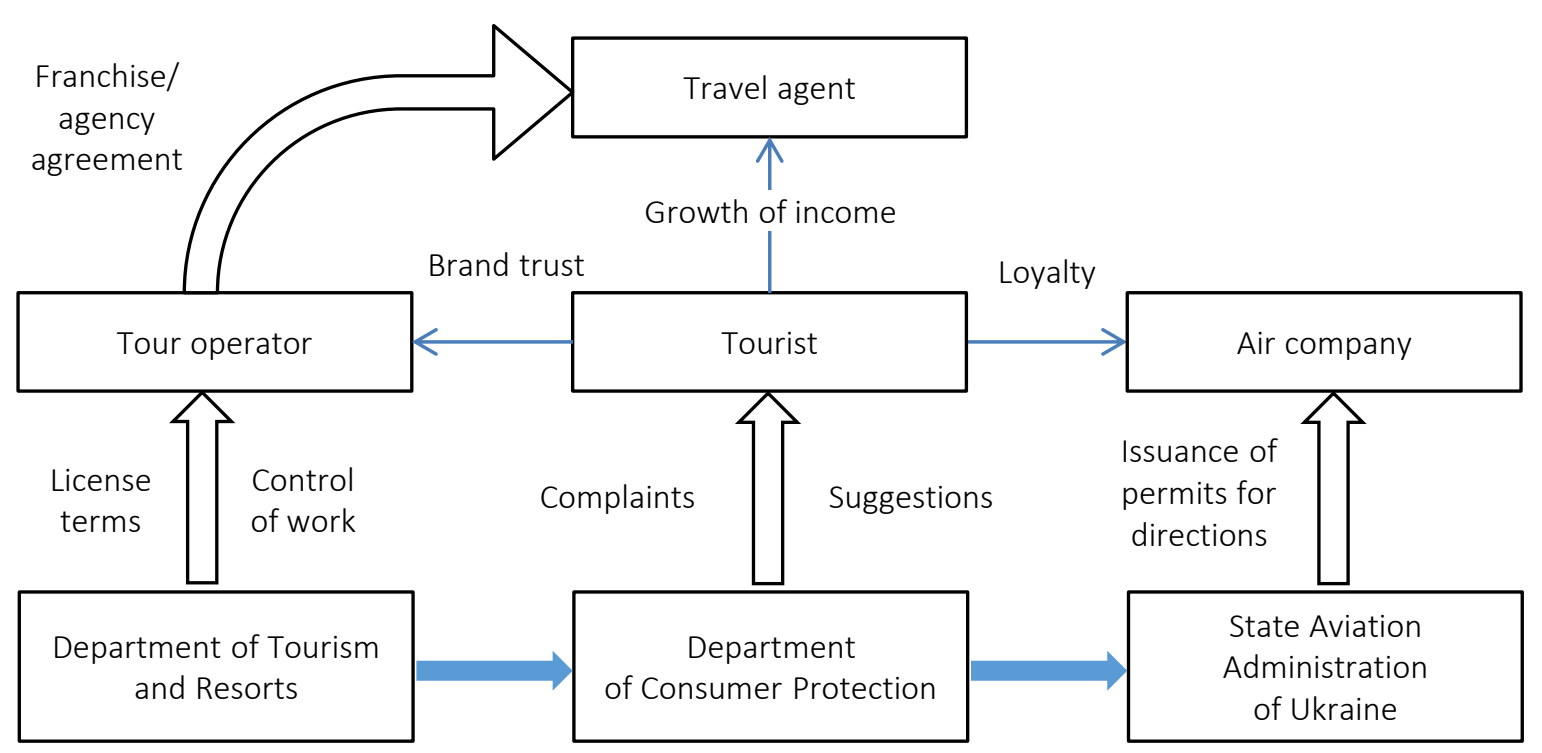

Figure 6. Interconnection of the actors of the charter air transportation market

ranking, the number of reviews, the quality of problem-solving, and the availability of fast feedback.

The use of the option of selecting an airlines, presented on the websites of tour operators, even for package tours, is not obvious for most tourists. However, the choice of the airlines can protect the consumer from the delay or cancellation of the flight. It is advisable to check the charter airlines both through websites with real reviews and through websites that display flights delays information (flightstats.com and the like).

A possible way to obtain the compensation in case of delay or cancellation of a flight (Arkhipov, Bazanov, Belozerov et al., 2017; Mustafina, Kaigorodova, Alyakina, Velichko, \& Zainullina, 2020 ) in other cases, is insurance (Kaigorodova \& Mustafina, 2014). Most Ukrainian insurance companies offer tourists not only a standard package of insurance services (O. Kozmenko, S. Kozmenko, \& Vasylieva, 2012, pp. 210-215; Sulkowska, 2013, pp. 379-389) but also those that include insurance against non-departure or delayed flight for some time (Achkasova, 2019). In this case, the increase in the standard insurance policy will be no more than $20 \%$. Given the rather low cost of travel insurance in Ukraine (Okhrimenko, 2008), such an increase in total travel costs is not tangible.
2. In the case of problems with the charter flights a tourist must act clearly according to the scheme: apply to the reception desk at the airport and write a complaint; receive a flight delay statement; formulate a collective appeal with the requirements to the airlines, which must perform this charter flight (it is advisable to give the copies of such appeal to the tour operator and the Office of Consumer Protection).

3. Post reviews of both positive and negative experience of interaction with the airlines on the relevant websites, websites of tour operators and airlines, as well as on social networks.

For the tour operator:

1. In order to increase the trust of customers and, accordingly, the reputation of tour operators, it would be a good idea to include a clause on compensation for a flight delay in the model agreement on the provision of tourist services, in accordance with the Convention (the Unification of Certain Rules for International Carriage by Air) on the liability of airlines in relation to transportation of passengers, baggage and cargo, including the difference and delay of flights. Ukraine is among 133 members of this convention since 2009 . 
2. In order to provide round-the-clock assistance, customer support service $24 / 7$ should be organized.

3. Use the experience of European tour operators to create their aviation fleet, as exemplified by TUI's largest tour operators in Europe (TUI Fly and five more charter airlines) and Thomas Cook (Thomas Cook Airlines).

For airlines:

1. Form a contractual relationship with tour operators in terms of volumes and directions of transportation in accordance with the actual technical condition of its own aviation fleet.

2. Formulate clear instructions for personnel aimed at solving conflict situations. The direct relationship between the airlines and the consumer of air transportation services is determined by the availability of an electronic ticket, which stipulates the airline's liability to the passenger for providing the relevant tourist services.

For State Aviation Administration of Ukraine:

In considering the appeals of the airlines for obtaining the right for regular and international charter air transportation from/to Ukraine, State Aviation Administration of Ukraine takes into account the results of the previous operation of the airlines, namely, the ability of the airlines to provide timely and quality services under the agreements with tour operators, in particular, to take into account flights delay statistics.

For Department of Tourism and Resorts:

Strengthen the licensing conditions for the tour operator's activity regarding the size and liquidity of the financial guarantee of the tour operator in view of the actual results of the activity in the previous period.

\section{CONCLUSION}

Consequently, the analysis showed that the charter air transportation market in Ukraine is not stable and regulated, and the relations of this market participants are only being formed. This leads to problems both in servicing the tourists and reduces the quality of tourist services for tourists.

The process of establishing a charter air transportation market in Ukraine does not keep up with the annual increase in the flow of passengers. The discrepancy between the number and quality of the fleet of leading charter airlines in Ukraine leads to the fact that a proportion the delayed flights increases up to $30 \%$.

An analysis of the activity of Ukrainian charter airlines confirms the expediency of as much as possible cooperation of the airlines with the tour operator. This conclusion does not contradict the positive experience of European tour operators with affiliated airlines and well-established schemes of interaction between all market participants.

The price remains the main criterion for choosing a tourist product for an average Ukrainian which is caused by both the state of the country's economy and the financial incomes of the consumer. Of course, this characteristic is typical of the unformed tourist services market, where the prevailing factor is not the criterion of quality but the competitive price.

The study allowed highlighting the issues and features of the charter air transportation market in Ukraine, formulating effective mechanisms for overcoming them and giving some practical recommendations to all participants when providing this service. 


\section{REFERENCES}

1. Achkasova, S. (2019). The scale measurement of the indicators of the stress resistance assessment of insurance companies in Ukraine. Economic Studies Journal, 2, 161-183. Retrieved from https:// ideas.repec.org/a/bas/econst/ y2019i2p161-183.html

2. Arkhipov, A., Bazanov, A., Belozerov, S., Boldyreva, N., Galkina, E., Gamankova, O. et al. (2017). Strakhovanie i upravlenie riskami: problemy i perspektivy: monografiya [Insurance and risk management: problems and perspectives: monograph]. Moscow: Prospekt. (In Russian). Retrieved from https://bit.ly/2Hwaa7K

3. Balabanov, G., \& Tkachuk, L. (2010). Analiz protsesiv vzaiemodii u systemi aviatsiiaturyzm [Analysis of interaction processes in the aviation-tourism system]. Naukovyi visnyk Instytutu mizhnarodnykh vidnosyn NAU - Scientific Herald of NAU International Relations Institute, 1 , 183-190. (In Ukrainian). Retrieved from http://jrnl.nau.edu.ua/index. php/IMV/article/view/2966/2924

4. Birzhakov, M. (2003). Industriya turizma: transport [Tourism industry: transport]. Moscow, Petersburg: Gerda Publishing House. (In Russian)

5. Boiko, M., Bosovska, M., Vedmid, N., Bovsh, L., \& Okhrimenko, A. (2018). Investment attractiveness of the Ukrainian tourism system. Investment Management and Financial Innovations, 15(4), 193209. https://doi.org/10.21511/ imfi.15(4).2018.16

6. Boiko, M., Bosovska, M., Vedmid, N., Melnychenko, S., \& Okhrimenko, A. (2017). Development of the tourism cluster. Problems and Perspectives in Management, 15(4), 134149. https://doi.org/10.21511/ ppm.15(4).2017.12

7. Buck, S., \& Lei, Zh. (2004). Charter Airlines: Have they a future? Tourism and Hospitality Research, 5(1), 72-78. Retrieved from https://www.jstor.org/ stable $/ 23743728$ ?seq=1
8. Dobruszkes, F., Koo, T., \& Lim, C. (2017). Causality in direct air services and tourism demand. Annals of Tourism Research, 67(C), 67-77. https://doi.org/10.1016/j. annals.2017.08.004

9. Doganis, R. (2001). The Airline Business in the 21st Century. London: Routledge.

10. Doktorov, A., \& Myshkyna, O. (2016). Organizatsiya transportnogo obsluzhivaniya $v$ turizme [Organization of transport services in tourism]. Moscow: Alfa-M. (In Russian)

11. Duncan, T. (2005). European Charter Airlines and In-Flight Catering Provision. Retrieved from http://epubs.surrey.ac.uk/1804/1/ fulltext.pdf

12. EUROCONTROL (2018). Delays - three questions and many answers. Retrieved from https://www.eurocontrol.int/news/delays-threequestions-and-many-answers

13. Forsyth, P. (2006). Tourism benefits and aviation policy. Journal of Air Transport Management, 12(1), 3-13. https://doi.org/10.1016/j.jairtraman.2005.09.001

14. Graham, A. (2006). Have the major forces driving leisure airline traffic changed? Journal of Air Transport Management, 12(1), 14-20. https://doi.org/10.1016/j. jairtraman.2005.09.002

15. International Air Transport Association (IATA) (2018). Multilateral Interline Traffic Agreements Retrieved from https:// www.iata.org

16. Kaigorodova, G., \& Mustafina, A (2014). The influence of forms of insurance coverage organization on population's life quality. Mediterranean Journal of Social Sciences, 5(24), 118-123. Retrieved from http://www.richtmann.org/ journal/index.php/mjss/article/ view/4948

17. Kozmenko, O., Kozmenko, S., \& Vasylieva, T. (2012). Novi vektory rozvytku strakhovoho rynku Ukrainy: monohrafiia [New vectors of Ukrainian insurance market development: monograph]. Sumy: Universytetska knyha. (In Ukrainian)

18. Legislation of Ukraine (1995). Zakon Ukrainy "Pro turyzm" [Law of Ukraine "On Tourism"]. (In Ukrainian). Retrieved from https://zakon.rada.gov.ua/laws/ show/324/95-\%D0\%B2\%D1\%80

19. Legislation of Ukraine (1998). Konventsiia pro unifikatsiiu deiakykh pravyl mizhnarodnykh povitrianykh perevezen [Convention on the Unification of Certain Rules for International Air Transportation]. (In Ukrainian). Retrieved from https://zakon.rada. gov.ua/laws/show/995_594

20. Legislation of Ukraine (2001). Pro zatverdzhennia Pravyl vykonannia charternykh reisiv [On approving the Rules for charter flights]. (In Ukrainian). Retrieved from https://zakon.rada.gov.ua/laws/ show/z0461-01

21. Legislation of Ukraine (2011). Povitrianyi kodeks Ukrainy [The Air Code of Ukraine]. (In Ukrainian). Retrieved from https://zakon.rada.gov.ua/laws/ show/3167-12/ed20150624

22. Legislation of Ukraine (2012). Pro zatverdzhennia Pravyl povitrianykh perevezen pasazhyriv ta bahazhu [On approving the Rules for air transportation of passengers and luggage]. (In Ukrainian). Retrieved from https://zakon.rada.gov.ua/laws/ show/z2219-12

23. Lintz, G., Muller, B., \& Schmude, K. (2007). The future of industrial cities and regions in central and eastern Europe. Geoforum, 38, 512-519. https://doi.org/10.1016/j. geoforum.2006.11.011

24. Mazaraki, A., Boiko, M., Okhrimenko, A., Melnychenko, S., \& Zubko, T. (2019). The impact of the national tourism system on the economic growth in Ukraine. Problems and Perspectives in Management, 17(4), 93103. https://doi.org/10.21511/ ppm.17(4).2019.08 
25. Merlo, P., Dankiewicz, R., \& Ostrowska-Dankiewicz, A. (2013). Probabilistic and statistical methods of risk analysis in the investments effectiveness evaluation and their application in business practice. Actual Problems of Economics, 12, 437446. Retrieved from https:// www.researchgate.net/publication/298650971_Probabilistic _ and_statistical_methods_of_risk_ analysis_in_the_investments_effectiveness_evaluation_and_their_ application_in_business_practice

26. Ministry of Infrastructure of Ukraine (MIU) (2018). [Reitynh punktualnosti ukrainskykh aviakompanii za cherven] [Ranking of Ukrainian airlines punctuality for June]. (In Ukrainian). Retrieved from https://mtu.gov.ua/news/29960. html

27. Mustafina, A., Kaigorodova, G., Alyakina, P., Velichko, N., \& Zainullina, M. (2020). Digital technology in insurance: Increasing livelihood security. In S. Ashmarina, A. Mesquita, \& M. Vochozka (Eds.), Digital Transformation of the Economy: Challenges, Trends and New Opportunities. Advances in Intelligent Systems and Computing, 908, 678-685. https://doi. org/10.1007/978-3-030-113674_65

28. Nesimko, O. (2015). Osoblyvosti dohovoru charteru povitrianoho sudna [Peculiarities of charter agreement of the aircraft]. Visnyk Natsionalnoho universytetu "Lvivska politekhnika". Yurydychni nauky - Herald of National University "Lviv Polytechnics". Legal sciences, 824, 179-185. (In Ukrainian). Retrieved from http:// journals.uran.ua/index.php/24153818/article/view/86746

29. Okhrimenko, A., Boiko, M., Bosovska, M., Melnychenko, S., \& Poltavska, O. (2019). Multisubject governance of the national tourism system. Problems and Perspectives in Management, 17(2), 165-176. https://doi.org/10.21511/ ppm.17(2).2019.12

30. Okhrimenko, O. (2008). Turystychnii sehment strakhovoho rynku Ukrainy: suchasni

tendentsii ta tekhnolohii rozvytku: monohrafiia [Tourist segment of Ukrainian insurance market: modern tendencies and development technologies: monograph]. Kyiv: Instytut demohrafii ta sotsialnykh doslidzhen NAN Ukrainy. (In Ukrainian)

31. Oleshko, T., \& Heiets, I. (2018). Perspectives of the air transportation market in Ukraine. Aviation, 22(1), 1-5. https://doi. org/10.3846/aviation.2018.1855

32. Oleshko, T., Heyets, I., \& Pavlyuk, Y. (2017). Analiz suchasnoho stanu aviatsii Ukrainy [Analysis of modern state of Ukrainian aviation]. Problemy systemnoho pidkhodu v ekonomitsi - Problems of systemic approach in economics, 5(61), 80-83. (In Ukrainian). Retrieved from http://er.nau.edu. ua/handle/NAU/35427

33. Papatheodorou, A. (Ed.) (2006). Corporate Rivalry and Market Power: Competition Issues in the Tourism Industry. London: IB Tauris.

34. Popov, V. (2016). Klasyfikatsiia dohovoriv, shcho ukladaiutsia u sferi perevezennia [Classification of agreements concluded in the transportation sphere]. Nashe pravo - Our right, 1, 150-157. (In Ukrainian).

35. Pyrkova, G., Kaigorodova, G., Mustafina, A., \& Alyakina, D. (2018). Financial risks: methodological approaches and management methods. Journal of Social Sciences Research, 5, 122127. https://doi.org/10.32861/jssr. spi5.122.127

36. Sarsfield, K. (2018). European business jet charter industry on the rise. Retrieved from https://www. flightglobal.com/news/articles/ european-business-jet-charterindustry-on-therise-444921

37. Smirnov, I. (2009). Lohistyka turyzmu [Tourism logistics]. Kyiv: Znannia. (In Ukrainian)

38. State Aviation Administration of Ukraine (SAAU) (2018). Statistical data in aviatransport. Retrieved from https://avia.gov.ua/en/
39. Sulkowska, W. (Ed.) (2013). Rynek ubezpieczen. Wspolczesne problemy. Warszawa: Difin.

40. Taylor, Z. (2016). Air charter leisure traffic and organized tourism in Poland: Are charters passé? Moravian geographical reports, 24(4), 15-25. https://doi. org/10.1515/mgr-2016-0019

41. YouControl (2017). FinScore bankruptcy probability tool. Retrieved from https://youcontrol. com.ua

42. Zhang, Y., \& Findlay, C. (2014). Air transport policy and its impacts on passenger traffic and tourist flows. Journal of Air Transport Management, 34, 42-48. https://doi.org/10.1016/j.jairtraman.2013.07.010 